\title{
Synthesis and characterization of impurities of an anti-psychotic drug substance, Olanzapine
}

\author{
Poornachander Thatipalli, ${ }^{\text {a }}$ Ramesh Kumar, ${ }^{\text {a }}$ Chandrasekhar Bulusu, ${ }^{a}$ Ramesh Chakka, \\ Pratap R. Padi, ${ }^{a}$ Anjaneyulu Yerra, ${ }^{b}$ and Satyanarayana Bollikonda, \\ ${ }^{a}$ Dr Reddy's Laboratories Limited, Bachupalli, Qutubullapur, Rangareddy District-72, Andhra \\ Pradesh, India. Fax: 914044346285 \\ ${ }^{b}$ Institute of Science and Technology, JNTU, Hyderabad. IPDO-IPM Communication No.00097 \\ E-mail: bsn2626@yahoo.com
}

\begin{abstract}
HPLC analysis of olanzapine 1, a known anti-psychotic drug, showed impurity peaks ranging from 0.05 to $0.15 \%$ during process development. These samples were analyzed by LCMS and the peaks were identified at $m / z 230,341,511,326,361$ and 329. All six impurities were synthesized individually and characterized based on their spectral data (IR, NMR and Mass). The structure of these impurities were assigned as 2-methyl-4,9-dihydro-3-thia-4,9diazabenzo[f]azulen-10-one $\quad \mathbf{4}, \quad$ 1-[4-(2-methyl-4H-3-thia-4,9-diazabenzo[f]azulen-10-yl) piperazin-1-yl]ethanone $\quad \mathbf{5}, \quad$ bis-[10-(2-methyl-4H-3-thia-4,9-diazabenzo[f]azulene)]-1,4piperazine 6, 2,4-dimethyl-10-(4-methylpiperazin-1-yl)-4H-3-thia-4,9-diazabenzo[f]azulene 7, 10-(4-chloromethyl-4-methylpiperazin-1-ylium)-2-methyl-4H-3-thia-4,9-diazabenzo[f]azulene chloride 8 and 2-methyl-10-(4-methyl- $N$-oxopiperazin-1-yl)-4H-3-thia-4,9-diazabenzo[f]azulene 9 respectively. The formation, synthesis and characterisation of the olanzapine impurities are discussed.
\end{abstract}

Keywords: Olanzapine, impurity profile, related substances

\section{Introduction}

Olanzapine 1, an atypical anti-psychotic $\operatorname{drug}^{1,2}$ with a thienobenzodiazepinyl structure, is indicated for the treatment of schizophrenia. It displays a broad pharmacological profile and is a selective monoaminergic antagonist with high affinity binding to serotonin $5 \mathrm{HT}_{2 \mathrm{~A} / 2 \mathrm{C}}$, dopamine $\mathrm{D}_{14}$, muscrinic $\mathrm{M}_{1-5}$ and adrenergic $\alpha_{1}$ receptors ${ }^{3,4,5}$.

The HPLC analysis of olanzapine displayed six impurity peaks in the range of 0.05 to $0.15 \%$ levels along with the olanzapine peak. As per the guidelines recommended by ICH, the acceptable level for a known or unknown related compound (impurity) is less than 0.15 and 0.10 
$\%$ respectively in a drug substance. In order to meet the stringent regulatory requirements, the impurities present in the drug substance must be identified and characterized. Our present work deals with the identification, synthesis and characterization of impurities/related substances of olanzapine 1.

\section{Results and Discussion}

Olanzapine was synthesized in the laboratory by a known pathway (Scheme 1) as per the literature method ${ }^{6}$ which involved the reaction of 2-methyl-4H-3-thia-4,9-diazabenzo[f]azulen10-ylamine hydrochloride $\mathbf{2}$ with piperazine to give $\mathbf{3}$, which on further methylation with dimethyl sulfate yielded olanzapine $\mathbf{1}$.

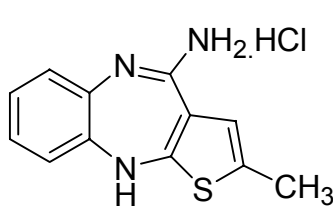

2

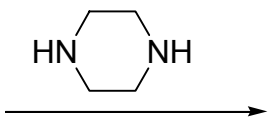<smiles>Cc1cc2c(s1)Nc1ccccc1N=C2N1CCNCC1</smiles>

3

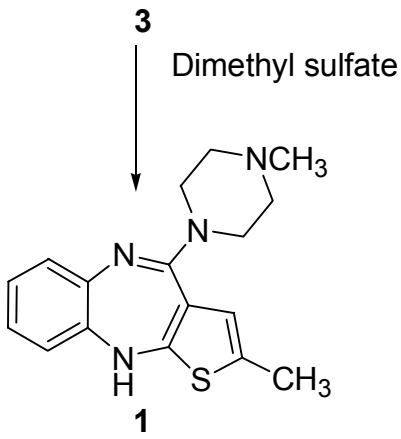

\section{Scheme 1}

A typical analytical LC chromatogram of a laboratory sample of olanzapine displayed impurities/related compounds over a range of $0.05-0.15 \%$. These impurities were identified, synthesized and characterized by spectral analysis. The assigned structures of these impurities are namely 2-methyl-4,9-dihydro-3-thia-4,9-diaza-benzo[f]azulen-10-one 4, 1-[4-(2-methyl-4H3-thia-4,9-diazabenzo[f]azulen-10-yl)-piperazin-1-yl]ethanone 5, bis-[10-(2-methyl-4H-3-thia4,9-diazabenzo[f]azulene)]-1,4-piperazine 6, 2,4-dimethyl-10-(4-methylpiperazin-1-yl)-4H-3thia-4,9-diazabenzo[f]azulene 7, 10-(4-chloromethyl-4-methylpiperazin-1-ylium)-2-methyl-4H3-thia-4,9-diazabenzo[f]azulene chloride 8 and 2-methyl-10-(4-methyl- $N$-oxopiperazin-1-yl)-4H3-thia-4,9-diazabenzo[f]azulene 9.

Impurity 4, a potential impurity formed during the synthesis of olanzapine due to basic reaction conditions, was prepared by reacting compound 2 with sodium hydroxide (Scheme 2). 


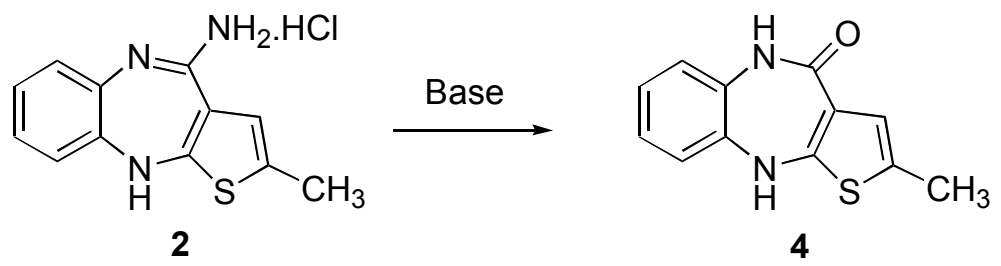

\section{Scheme 2}

Acetic acid is used in the work-up of the olanzapine synthesis. Thus compound 3 was $N$ acetylated resulting in the formation of impurity 5. This impurity was synthesized quantitatively by the reaction of compound $\mathbf{3}$ with acetic anhydride (Scheme 3 ).

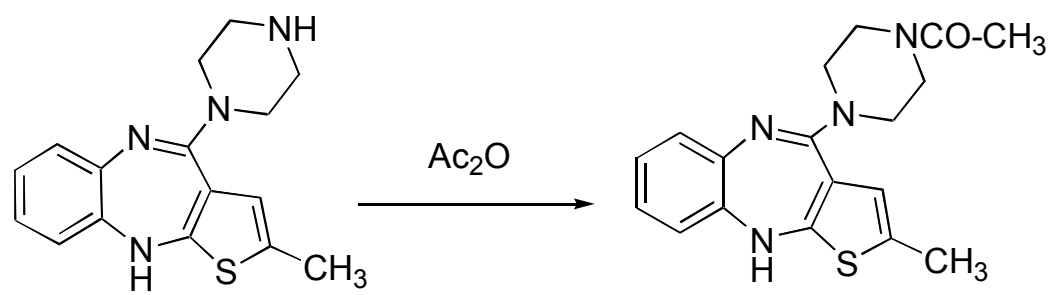

3

5

\section{Scheme 3}

Any residual 2 present in the reaction reacts with compound 3 to give impurity 6 . This impurity is formed only in trace quantities (Scheme 4).

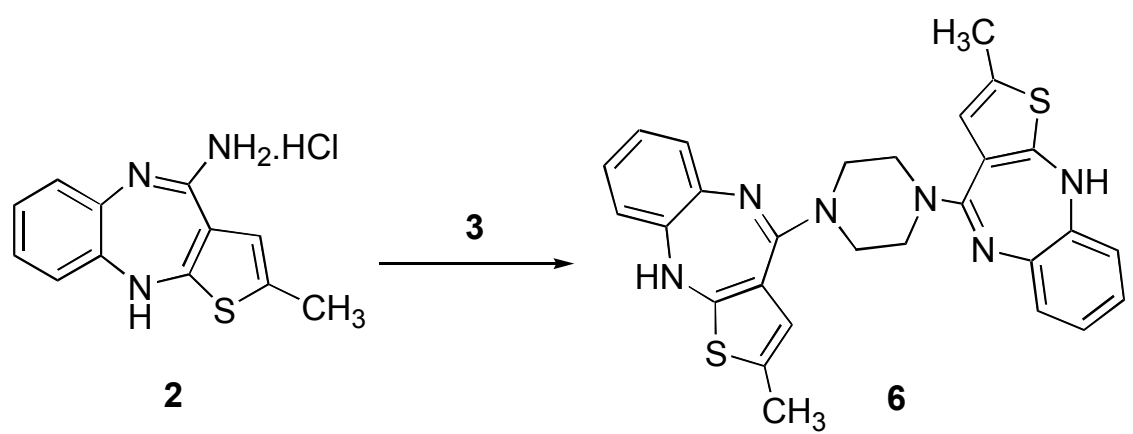

\section{Scheme 4}

Methylation of compound 3 with dimethyl sulfate forms olanzapine 1 (Scheme 1) however, as a side reaction, the free $\mathrm{NH}$ group present in the diazabenzoazulene moiety of $\mathbf{1}$ is methylated, resulting in impurity 7 . This impurity was synthesized by the reaction of olanzapine with excess dimethyl sulfate (Scheme 5). 


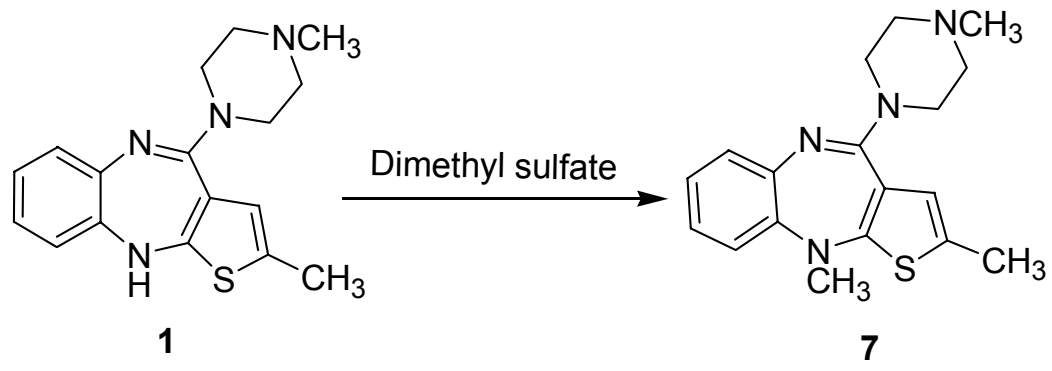

\section{Scheme 5}

Compound $\mathbf{8}$, is formed by the reaction of olanzapine $\mathbf{1}$ with dichloromethane, a solvent that is used for the final purification of olanzapine. This impurity was synthesized by prolonged contact of olanzapine with dichloromethane at elevated temperatures and its structure was further confirmed by its spectral data (Scheme 6).
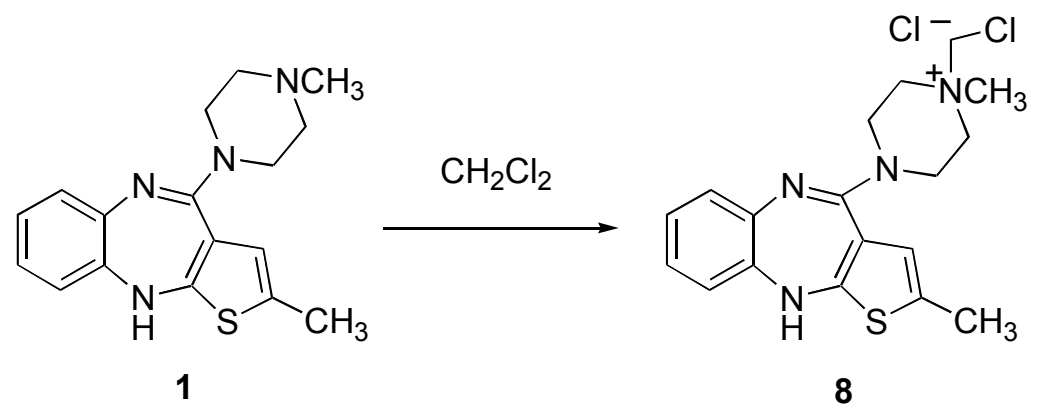

\section{Scheme 6}

Impurity 9 is formed in traces due to aerial oxidation of olanzapine 1. This impurity was synthesized by the oxidation of olanzapine 1 with $m$-chloroperbenzoic acid and was purified by column chromatography (Scheme 7).
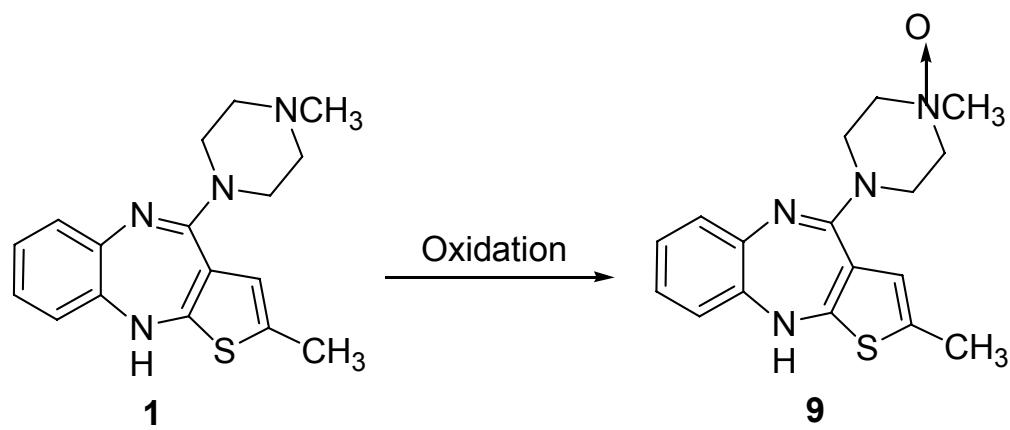

Scheme 7 


\section{Experimental Section}

General Procedures. ${ }^{1} \mathrm{H}$ NMR spectra were recorded on a Gemini $200 \mathrm{MHz}$ FT NMR spectrometer; the chemical shifts are reported in $\delta \mathrm{ppm}$ relative to TMS. The IR spectra were recorded in the solid state as $\mathrm{KBr}$ dispersion using Perkin Elmer FT-IR Spectrophotometer. The mass spectra were recorded on Shimadzu LCMS-QP8000, LC-MS and AB-4000 Q-trap LCMS/MS.

\section{2-Methyl-4,9-dihydro-3-thia-4,9-diazabenzo[f]azulen-10-one (4)}

A mixture of 2-methyl-4H-3-thia-4,9-diazabenzo[f]azulen-10-ylamine hydrochloride $(2,50.0 \mathrm{~g}$, $0.19 \mathrm{~mol})$ and $30 \%$ aqueous sodium hydroxide $(200 \mathrm{~mL})$ were heated to reflux till reaction was complete. The reaction mixturre was cooled to room temperature and the resulting solid was filtered and washed with water $(100 \mathrm{~mL})$. The resultant wet cake was dissolved in methanol $(1000 \mathrm{~mL})$ at reflux, treated with carbon $(5.0 \mathrm{~g})$ and finally water $(500 \mathrm{~mL})$ was added precipitating a solid. The isolated solid was filtered, washed with water $(100 \mathrm{~mL})$ and dried at $70{ }^{\circ} \mathrm{C}$ to yield compond 4 (Yield: $35 \mathrm{~g}$; HPLC Purity: >99 \%). IR ( $\left.\mathrm{cm}^{-1}\right): 3281,3191(\mathrm{NH}), 1637$ (CO); ${ }^{1} \mathrm{H}$ NMR (DMSO-d 6 , $\delta$ ppm): $2.2\left(\mathrm{~s}, 3 \mathrm{H}, \mathrm{CH}_{3}\right), 6.6(\mathrm{~s}, 1 \mathrm{H}, \mathrm{CH}), 6.9(\mathrm{~m}, 4 \mathrm{H}, \mathrm{Ar}-\mathrm{H}), 7.6$ (s, $1 \mathrm{H}, \mathrm{NH})$; Mass: $230\left(\mathrm{M}^{+}\right) ; \mathrm{C} \mathrm{H} \mathrm{N}$ Analysis Calcd. for $\mathrm{C}_{12} \mathrm{H}_{10} \mathrm{~N}_{2} \mathrm{OS}$ : C, 62.59; H, 4.38; N, $12.16 \%$ Found: C, $62.36 ; \mathrm{H}, 4.57 ; \mathrm{N}, 12.20 \%$

\section{1-[4-(2-Methyl-4H-3-thia-4,9-diazabenzo[f]azulen-10-yl)piperazin-1-yl]ethanone (5)}

To a stirred mixture of 2-methyl-10-piperazin-1-yl-4H-3-thia-4,9-diazabenzo[f]azulene $(3,2.5 \mathrm{~g}$, $0.008 \mathrm{~mol})$ and dichloromethane $(50 \mathrm{~mL})$, triethylamine $(1.3 \mathrm{~mL})$ was added slowly. The reaction mixture was cooled to $5{ }^{\circ} \mathrm{C}$ and to it, acetic anhydride $(1.0 \mathrm{~mL})$ was added and the mixture stirred until the reaction was complete. Water $(10 \mathrm{~mL})$ was added and the organic and aqueous layers were separated. The organic layer was washed with water $(4 \times 10 \mathrm{~mL})$ and concentrated under reduced pressure to a minimum volume for solid separation. The separated solid was filtered, washed with dichloromethane $(5 \mathrm{~mL})$ and dried to a constant weight to yield compound 5 (Yield: 2.5 g; HPLC purity: $97 \%$ ); IR $\left(\mathrm{cm}^{-1}\right)$ : $1642(\mathrm{C}=\mathrm{O}), 3248(\mathrm{NH})$; ${ }^{1} \mathrm{H}$ NMR $\left(\mathrm{CDCl}_{3}, \delta \mathrm{ppm}\right): 2.0-2.1\left(\mathrm{~s}, 3 \mathrm{H}, \mathrm{CH}_{3}\right), 2.3(\mathrm{~s}, 3 \mathrm{H}, \mathrm{CH} 3), 3.0-3.6\left(\mathrm{~m}, 8 \mathrm{H}, \mathrm{CH}_{2}\right), 6.4(\mathrm{~s}, 1 \mathrm{H}, \mathrm{Ar}-\mathrm{H})$, 6.7-6.9 (m, 4H, Ar-H), $7.6(\mathrm{~s}, 1 \mathrm{H}, \mathrm{NH})$; Mass: $341\left(\mathrm{M}^{+1}\right)$; $\mathrm{C} \mathrm{H} \mathrm{N} \mathrm{Analysis} \mathrm{Calcd.} \mathrm{for}$ $\mathrm{C}_{18} \mathrm{H}_{20} \mathrm{~N}_{4} \mathrm{OS}$ : C, 63.50; H, 5.92; N, 16.46\% Found: C, 63.72; H, 5.99; N, 16.35\%

\section{Bis-[10-(2-methyl-4H-3-thia-4,9-diazabenzo[f]azulene)]-1,4-piperazine (6)}

A mixture of 2-methyl-10-piperazin-1-yl-4H-3-thia-4,9-diazabenzo[f]azulene (3, $10.0 \mathrm{~g}, 0.034$ mol), dimethyl sulfoxide $(10 \mathrm{~mL})$, toluene $(40 \mathrm{~mL})$ and 2-methyl-4H-3-thia-4,9diazabenzo[f]azulen-10-ylamine hydrochloride $(2,9.0 \mathrm{~g}, 0.034 \mathrm{~mol})$ was heated to reflux. Triethylamine $(20 \mathrm{~mL})$ was added in three equal portions to the reaction mixture at reflux temperature and the reaction mass was stirred for reaction completion. The reaction mixture was cooled to $35{ }^{\circ} \mathrm{C}$ and the undissolved material was filtered off. The filtrate was concentrated under 
reduced pressure. To the residue, water $(50 \mathrm{~mL})$ was added and the mixture was stirred for solid separation. The isolated solid was filtered, washed with aqueous methanol and dried at $60{ }^{\circ} \mathrm{C}$ to a constant weight to yield compound 6 (Yield: $10.1 \mathrm{~g}$, HPLC purity: $93.0 \%$ ); IR $\left(\mathrm{cm}^{-1}\right): 3375$ $(\mathrm{NH}) ;{ }^{1} \mathrm{H}$ NMR $\left(\mathrm{CDCl}_{3}, \delta \mathrm{ppm}\right): 2.2-2.3\left(\mathrm{~s}, 6 \mathrm{H}, \mathrm{CH}_{3}\right), 3.2-3.5\left(\mathrm{~m}, 8 \mathrm{H}, \mathrm{CH}_{2}\right), 6.4(\mathrm{~s}, 2 \mathrm{H}, \mathrm{Ar}-\mathrm{H})$, 6.7-6.9 (m, 8H, Ar-H), $7.7(\mathrm{~s}, 2 \mathrm{H}, \mathrm{NH})$; Mass: $511\left(\mathrm{M}^{+1}\right)$; $\mathrm{C} \mathrm{H} \mathrm{N} \mathrm{Analysis} \mathrm{Calcd.} \mathrm{for}$ $\mathrm{C}_{28} \mathrm{H}_{26} \mathrm{~N}_{6} \mathrm{~S}_{2}: \mathrm{C}, 65.85 ; \mathrm{H}, 5.13 ; \mathrm{N}, 16.46 \%$ Found: $\mathrm{C}, 65.82 ; \mathrm{H}, 5.21 ; \mathrm{N}, 16.35 \%$

\section{2, 4-Dimethyl-10-(4-methylpiperazin-1-yl)-4H-3-thia-4,9-diazabenzo[f]azulene (7)}

To a stirred mixture of olanzapine $(1,2.5 \mathrm{~g})$ and dichloromethane $(15 \mathrm{~mL})$, dimethyl sulfate $(3.5$ $\mathrm{mL}$ ) was added slowly at $35^{\circ} \mathrm{C}$ and the mixture stirred for reaction completion. The resultant solid was filtered off, washed successively with dichloromethane $(10 \mathrm{~mL}), n$-hexane $(10 \mathrm{~mL})$, dried at $65{ }^{\circ} \mathrm{C}$ to a constant weight and finally recrystallized from toluene $(15 \mathrm{~mL})$ to yield compound 7 (Yield: 2.4 g, HPLC Purity: 98\%); ${ }^{1} \mathrm{H} \mathrm{NMR}\left(\mathrm{CDCl}_{3}, \delta \mathrm{ppm}\right): 2.2\left(\mathrm{~s}, 3 \mathrm{H}, \mathrm{CH}_{3}\right), 2.4$ (s, 3H, $\left.\mathrm{CH}_{3}\right), 2.8\left(\mathrm{~s}, 3 \mathrm{H}, \mathrm{CH}_{3}\right), 3.3-3.5\left(\mathrm{~m}, 4 \mathrm{H}, \mathrm{CH}_{2}\right), 4.0\left(\mathrm{~m}, 4 \mathrm{H}, \mathrm{CH}_{2}\right), 6.3(\mathrm{~s}, 1 \mathrm{H}, \mathrm{Ar}-\mathrm{H}), 6.5$ (d, $1 \mathrm{H}, \mathrm{Ar}-\mathrm{H}), 6.8-7.0(\mathrm{~m}, 3 \mathrm{H}, \mathrm{Ar}-\mathrm{H})$; Mass: $326\left(\mathrm{M}^{+1}\right)$; $\mathrm{C} \mathrm{H} \mathrm{N}$ Analysis Calcd. for $\mathrm{C}_{18} \mathrm{H}_{22} \mathrm{~N}_{4} \mathrm{~S}$ : C, 66.22 ; H, 6.79; N, 17.16\% Found: C, 66.32; H, 6.53; N, 17.22\%

\section{0-(4-Chloromethyl-4-methylpiperazin-1-ylium)-2-methyl-4H-3-thia-4,9-diazabenzo[f]- azulene chloride (8)}

Olanzapine $(1,12.5 \mathrm{~g}, 0.034 \mathrm{~mol})$ in dichloromethane $(125 \mathrm{~mL})$ was stirred at reflux for reaction completion. The reaction mass was concentrated to a minimum volume at $45{ }^{\circ} \mathrm{C}$. The isolated solid was filtered off, washed with dichloromethane $(65.0 \mathrm{~mL})$ and dried at $35{ }^{\circ} \mathrm{C}$ to a constant weight. The solid was stirred in hot methanol $(10.0 \mathrm{~mL})$ at $65{ }^{\circ} \mathrm{C}$, filtered, washed with methanol $(3.0 \mathrm{~mL})$ and dried at $35{ }^{\circ} \mathrm{C}$ to yield 8 (Yield: $10.5 \mathrm{~g}$, HPLC purity: $97 \%$ ); IR $\left(\mathrm{cm}^{-1}\right)$ : $3212(\mathrm{NH}) ;{ }^{1} \mathrm{H}$ NMR $\left(\mathrm{CDCl}_{3}, \delta \mathrm{ppm}\right): 2.3\left(\mathrm{~s}, 3 \mathrm{H}, \mathrm{CH}_{3}\right), 3.3\left(\mathrm{~s}, 3 \mathrm{H}, \mathrm{CH}_{3}\right), 3.5-3.9\left(\mathrm{~m}, 8 \mathrm{H}, \mathrm{CH}_{2}\right)$, 5.7 (s, 2H, $\left.\mathrm{CH}_{2}\right), 6.4$ (s, 1H, Ar-H), 6.7-6.9 (m, 4H, Ar-H), 7.7 (s, 1H, NH); Mass: 361 (M-35.5); C H N Analysis Calcd. for $\mathrm{C}_{18} \mathrm{H}_{22} \mathrm{Cl}_{2} \mathrm{~N}_{4} \mathrm{~S}: \mathrm{C}, 54.35 ; \mathrm{H}, 5.54 ; \mathrm{N}, 14.09 \%$ Found: C, 54.38; H, $5.65 ; \mathrm{N}, 14.05 \%$

\section{2-Methyl-10-(4-methyl- $\boldsymbol{N}$-oxopiperazin-1-yl)-4H-3-thia-4,9-diazabenzo[f $]$ azulene (9)}

To a mixture of olanzapine $(1,12.5 \mathrm{~g}, 0.034 \mathrm{~mol})$ in acetic acid $(62.5 \mathrm{~mL}) \mathrm{m}$-chloroperbenzoic acid $(7.0 \mathrm{~g}, 0.04 \mathrm{~mol})$ was added and the mixture stirred at $50{ }^{\circ} \mathrm{C}$ for reaction completion. The reaction mass was concentrated under reduced pressure and the residual mass was dissolved in dichloromethane $(50 \mathrm{~mL})$. The resultant solution was washed with water, concentrated under reduced pressure and finally purified by column chromatography to yield compound 9 (Yield: 8 g, HPLC purity: 94\%); IR $\left(\mathrm{cm}^{-1}\right): 3218(\mathrm{NH}) ;{ }^{1} \mathrm{H} \mathrm{NMR}\left(\mathrm{CDCl}_{3}, \delta \mathrm{ppm}\right): 2.3\left(\mathrm{~s}, 3 \mathrm{H}, \mathrm{CH}_{3}\right), 3.2(\mathrm{~s}$, $\left.3 \mathrm{H}, \mathrm{CH}_{3}\right), 3.3-3.5\left(\mathrm{~m}, 4 \mathrm{H}, \mathrm{CH}_{2}\right), 4.0\left(\mathrm{~m}, 4 \mathrm{H}, \mathrm{CH}_{2}\right), 6.3(\mathrm{~s}, 1 \mathrm{H}, \mathrm{Ar}-\mathrm{H}), 6.5(\mathrm{~d}, 1 \mathrm{H}, \mathrm{Ar}-\mathrm{H}), 6.8-7.0$ $(\mathrm{m}, 3 \mathrm{H}, \mathrm{Ar}-\mathrm{H}), 7.6(\mathrm{~s}, 1 \mathrm{H}, \mathrm{NH})$; Mass: $329\left(\mathrm{M}^{+1}\right)$; $\mathrm{C} \mathrm{H} \mathrm{N}$ Analysis Calcd. for $\mathrm{C}_{17} \mathrm{H}_{20} \mathrm{~N}_{4} \mathrm{OS}$ : C, 62.17; H, 6.14; N, 17.06\% Found: C, 62.15; H, 6.18; N, 17.12\% 


\section{Acknowledgements}

The authors wish to thank the management of Integrated Product Development Division of Dr. Reddy's Laboratories Ltd., for supporting this work.

\section{References}

1. Adams, C. E.; Fenton, M. K.; Quraishi, S; David, A. S. Br. J. Psychiatry 2001, 179, 290.

2. Chakrabarti, J. K.; Hotten, T. M.; Tupper, D. E. US Patent No. 5229382, 1993.

3. Moore, N. A.; Tye, N. C.; Axton, M. S.; Risius, F. C. J. Pharmacol. Exper. Ther. 1992, 262, 545.

4. Moore, N. A.; Calligaro, D. O.; Wong, D. T.; Bymaster, F.; Tye, N. C. Curr. Opin. Invest. Drugs 1993, 2, 281.

5. Tamminga, C. A. J. Neural. Transm. 2002, 109, 411.

6. Venkatraman, S.; Rajan, S. T.; Bulusu, V. V. N. C. S.; Kasturi, R. K.; Kapabalu, S. K.; Gokavalasa, K. US Patent Appln. 2006,0035887, 2006. 